\title{
Therapeutic effect of oral doxycycline on syphilis
}

\author{
YOICHI ONODA \\ From the Tokyo Metropolitan Taito Hospital, and the Kyorin University School of Medicine, Tokyo, Japan
}

SUMMARY Fifty-one patients with syphilis were treated with oral doxycycline. A course of the antibiotic treatment consisted of $200 \mathrm{mg}$ of doxycycline daily in two divided doses for 28 days. The courses were repeated three to four times a year with an interval of several months. Quantitative Venereal Disease Research Laboratory(VDRL), Wassermann reaction(WR), and Treponema pallidum haemagglutination assay (TPHA) tests were performed monthly to evaluate the therapeutic effect of doxycycline treatment. The response rate was $100 \%$ for primary, $90 \%$ for early, $68 \%$ for late, and $90 \%$ for congenital syphilis in adults. No notable side effects were encountered except for epigastric fullness in one patient, which did not require the treatment to be discontinued. No abnormalities were detected in the results of laboratory tests.

\section{Introduction}

When given orally in the treatment of syphilis conventional antibiotics should be administered every six hours because of the short duration of their effective blood concentrations. Since antisyphilitic treatments usually need to be carried out over long periods of time, patients may not strictly follow the treatment regimen.

Although the tetracycline group of antibiotics, including tetracycline itself and oxytetracycline, is known to have a treponemicidal action, these drugs should be given every six hours by mouth to maintain an effective blood concentration. The usual daily dose is $1 \mathrm{~g}$ in adults. The continuous use of tetracycline and oxytetracycline over long periods of time may cause a deposit of yellow pigment in the bone. Yellowish discoloration may develop in the teeth of children whose mothers have been given these tetracyclines during pregnancy. Other side effects such as a black tongue also occur in a few cases relatively early in the treatment and leads to discontinuing the administration. Accordingly, tetracycline and oxytetracycline are not satisfactory oral antibiotics in the treatment of syphilis.

The effective blood concentration of doxycycline (DOTC), a derivative of tetracycline, lasts for a period of 12 hours or longer after an oral dose of $100 \mathrm{mg}$. The daily dose of $200 \mathrm{mg}$ (in two equal

Address for reprints: Dr Y. Onoda, Tokyo Metropolitan Taito Hospital, 5-20-3 Senzoku Taitoku, Tokyo III, Japan.

Received for publication 7 September 1978 doses) of DOTC, therefore, is one-fifth of that of conventional tetracyclines and will rarely cause any side effects; furthermore, two doses daily are more convenient for patients than four doses daily.

This paper describes the results of DOTC therapy for syphilis over a period of eight years.

\section{Material and methods}

PATIENTS

DOTC therapy was given to 51 patients with various stages of syphilis. Thirty-five patients with primary, early, or adult congenital syphilis had had no previous treatment, while seven of 16 patients with late latent syphilis had previously been given some antisyphilitic treatment.

\section{DOSAGE AND ADMINISTRATION OF}

DOXYCYCLINE

A dose of $100 \mathrm{mg}$ DOTC was given orally, immediately after the morning and evening meal. A course of DOTC treatment consisted of daily administration at this dosage over a period of four weeks (28 days) and was repeated every three to four months. Accordingly, patients received three to four courses of the treatment annually.

\section{LABORATORY TESTS}

Quantitative Wassermann reaction (WR), Venereal Disease Research Laboratory (VDRL), and Treponema pallidum haemagglutination (TPHA) tests were repeated once a month during the observation period in each case. Liver function was checked by 
repeat determinations of serum aspartate transaminase (SGOT) and serum alanine aminotransferase (SGPT) levels at appropriate intervals.

\section{OBSERVATION PERIOD}

Observation periods ranged between two and nine months for five cases with primary syphilis; this period was short because the disease required only short periods of time for cure. Ten cases with early syphilis were followed over periods up to five years and seven months, 16 cases with late latent syphilis for up to four years and ten months, and 20 cases with adult congenital syphilis for up to seven years and nine months. Physical examination and laboratory tests were repeated every month in each case during the observation period.

\section{CRITERIA FOR RESPONSE TO TREATMENT}

The result of DOTC therapy was evaluated by comparing titres of the VDRL and WR tests before and after treatment. The response was considered excellent when titres of both tests decreased by more than two dilutions and when the titre of one test was decreased by one dilution or not at all but that of the other test was decreased by more than two dilutions. A good response was so defined when the titre of one test was decreased by two dilutions but the titre of the other test was decreased by one dilution or remained unchanged. The response was evaluated as poor when only a one dilution difference was observed in the titre of one test before and after DOTC therapy but none in the titre of the other test, or no difference was found in the titre of either test before and after treatment (Table 1).

\section{Results}

\section{PRIMARY SYPHILIS}

Laboratory data for a patient with primary syphilis whose antibody titres were decreasing to zero at short intervals after DOTC therapy are shown in Table 2.

Table 1 Criteria for response to oral doxycycline therapy

\begin{tabular}{lll}
\hline \multirow{2}{*}{ Response } & \multicolumn{2}{c}{ Decrease in antibody titre (dilutions)* } \\
\cline { 2 - 3 } Excellent & VDRL & $W R$ \\
\cline { 2 - 3 } Good & 2 & 2 \\
& 2 & 1 \\
Poor & 2 & 0 \\
& 2 & 1 \\
& 2 & 0 \\
& 1 & 1 \\
& 1 & 0 \\
& 0 & 0
\end{tabular}

*Difference in dilutions before and after treatment
The results of the serological tests for syphilis reverted to normal in each of five patients with primary syphilis at the end of DOTC therapy, which ranged in duration from two to nine months. Thus, the response was excellent in all of the five cases (Table 3).

\section{SECONDARY SYPHILIS}

The course of a case of early syphilis is shown in Table 4; an excellent response to DOTC therapy was seen during the observation period of one year and nine months.

Ten patients with secondary syphilis were treated with the same regimen. The shortest observation period was four months in four patients, while one patient was followed up for a period as long as five years and seven months (Table 5). The response to DOTC therapy was excellent in five patients, good in four, and poor in the remaining one. The patient with a poor response has been followed up for a period of only four months. Since excellent responses were achieved in two patients followed up for comparable periods of time, however, an evaluation of poor response was made in this patient.

\section{LATE SYPHILIS}

In one patient alopecia had developed due to a syphilitic infection which had occurred 10 years previously and was unnoticed and untreated (Table 6). Oral DOTC therapy consisting of 12 courses during a period of four years and four months produced an excellent response in this patient.

Of 16 cases of late syphilis nine had had no previous treatment while seven had previously received arsenicals or bismuth preparations. Of 16 cases with late syphilis, six $(37.5 \%)$ responded excellently, five $(31.3 \%)$ well, and five $(31.3 \%)$ poorly to the treatment. Of nine cases previously untreated, five $(55.6 \%)$ showed excellent responses, and four $(44.4 \%)$ good responses (Table 7$)$.

\section{ADULT CONGENITAL SYPHILIS}

A female patient who had positive results to serological tests at a premarital examination responded excellently to oral DOTC therapy. She received 21 courses during a period of seven years and nine months (Table 8).

Of 20 patients with adult congenital syphilis who had had no previous treatment, $12(60.0 \%)$ showed excellent responses, six $(30.0 \%)$ good responses, and two $(10.0 \%)$ poor responses (Table 9$)$.

\section{SIDE EFFECTS}

Epigastric fullness occurred in some patients, but it was only transient. No patient had to stop treatment because of gastrointestinal disturbances. 
Table 2 Laboratory data for a 36-year-old male patient with primary syphilis

\begin{tabular}{|c|c|c|c|c|c|}
\hline \multirow[b]{2}{*}{ Date of examination } & \multirow{2}{*}{$\begin{array}{l}\text { Observation period } \\
\text { (months) }\end{array}$} & \multicolumn{3}{|c|}{ Antibody titres } & \multirow{2}{*}{$\begin{array}{l}\text { Course of DOTC } \\
\text { therapy* }\end{array}$} \\
\hline & & $V D R L$ & $W R$ & $T P H A$ & \\
\hline $\begin{array}{l}\text { October } 1972 \\
\text { November } 1972 \\
\text { February } 1973 \\
\text { March } 1973 \\
\text { July } 1973\end{array}$ & $\begin{array}{l}0 \\
1 \\
4 \\
5 \\
9\end{array}$ & $\begin{array}{r}16 \\
4 \\
0 \\
0 \\
0\end{array}$ & $\begin{array}{r}64 \\
16 \\
0 \\
0 \\
0\end{array}$ & $\begin{array}{l}320 \\
320 \\
320 \\
320 \\
320\end{array}$ & $\begin{array}{l}\text { 1st } \\
\text { 2nd }\end{array}$ \\
\hline
\end{tabular}

*Each course consisted of daily doses of $200 \mathrm{mg}$ for 28 days

Table 3 Laboratory data for five patients with primary syphilis

\begin{tabular}{|c|c|c|c|c|c|c|c|c|c|c|c|}
\hline \multirow[b]{3}{*}{ Case no. } & \multirow{3}{*}{$\begin{array}{l}\text { Age } \\
\text { (yrs) }\end{array}$} & \multirow[b]{3}{*}{ Sex } & \multicolumn{6}{|c|}{ Antibody titres } & \multirow{3}{*}{$\begin{array}{l}\text { Observa- } \\
\text { tion } \\
\text { period } \\
\text { (months) }\end{array}$} & \multirow{3}{*}{$\begin{array}{l}\text { No. of } \\
\text { courses } \\
\text { of } \\
\text { DOTC } \\
\text { therapy }\end{array}$} & \multirow[b]{3}{*}{ Response } \\
\hline & & & \multicolumn{3}{|c|}{ Before treatment } & \multicolumn{3}{|c|}{ After treatment } & & & \\
\hline & & & $V D R L$ & $W R$ & $T P H A$ & $V D R L$ & $W R$ & $T P H A$ & & & \\
\hline 1 & 36 & $\mathbf{M}$ & 16 & 64 & 320 & 0 & 0 & 320 & 9 & 2 & Excellent \\
\hline 2 & 29 & $\mathbf{M}$ & 4 & 16 & 0 & 0 & 0 & 0 & 6 & 1 & Excellent \\
\hline 3 & 32 & $\mathbf{M}$ & 2 & 40 & 1280 & 0 & 0 & 1280 & 4 & 1 & Excellent \\
\hline 4 & 41 & $\mathbf{M}$ & $3 \overline{2}$ & 1024 & 5120 & 4 & 64 & 5120 & 3 & 1 & Excellent \\
\hline 5 & 26 & $\mathbf{M}$ & 1 & 0 & 0 & 0 & 0 & 0 & 2 & 1 & Excellent \\
\hline
\end{tabular}

Table 4 Laboratory data for a 56-year-old male patient with early syphilis

\begin{tabular}{|c|c|c|c|c|c|}
\hline \multirow[b]{2}{*}{ Date } & \multirow{2}{*}{$\begin{array}{l}\text { Observation period } \\
\text { (months) }\end{array}$} & \multicolumn{3}{|c|}{ Antibody titres } & \multirow{2}{*}{$\begin{array}{l}\text { Course of DOTC } \\
\text { therapy* }\end{array}$} \\
\hline & & $V D R L$ & $W R$ & $T P H A$ & \\
\hline $\begin{array}{l}\text { August } 1975 \\
\text { September } 1975 \\
\text { October } 1975 \\
\text { December } 1975 \\
\text { January } 1976 \\
\text { February } 1976 \\
\text { April } 1976 \\
\text { November } 1976 \\
\text { January } 1977 \\
\text { March } 1977\end{array}$ & $\begin{array}{r}0 \\
1 \\
2 \\
4 \\
5 \\
6 \\
8 \\
15 \\
17 \\
21\end{array}$ & $\begin{array}{r}32 \\
32 \\
32 \\
32 \\
8 \\
8 \\
8 \\
4 \\
2 \\
2\end{array}$ & $\begin{array}{r}128 \\
256 \\
256 \\
128 \\
64 \\
32 \\
64 \\
16 \\
8 \\
16\end{array}$ & $\begin{array}{l}5120 \\
5120 \\
5120 \\
1280 \\
5120 \\
5120 \\
1280 \\
5120 \\
1280 \\
1280\end{array}$ & $\begin{array}{l}\text { First } \\
\text { Second } \\
\text { Third } \\
\text { Fourth } \\
\text { Fifth }\end{array}$ \\
\hline
\end{tabular}

*Each course consisted of $200 \mathrm{mg}$ daily for 28 days

Table 5 Laboratory data for 10 patients with early syphilis

\begin{tabular}{|c|c|c|c|c|c|c|c|c|c|c|c|}
\hline \multirow[b]{3}{*}{ Case no. } & \multirow[b]{3}{*}{ Age (yrs) } & \multirow[b]{3}{*}{$\operatorname{Sex}$} & \multicolumn{6}{|c|}{ Antibody titres } & \multirow{3}{*}{$\begin{array}{l}\text { Observation } \\
\text { period } \\
\text { (months) }\end{array}$} & \multirow{3}{*}{$\begin{array}{l}\text { No. of } \\
\text { courses of } \\
\text { DOTC } \\
\text { therapy }\end{array}$} & \multirow[b]{3}{*}{ Response } \\
\hline & & & \multicolumn{3}{|c|}{ Before treatment } & \multicolumn{3}{|c|}{ After treatment } & & & \\
\hline & & & $V D R L$ & $W R$ & $T P H A$ & $V D R L$ & $W R$ & $T P H A$ & & & \\
\hline $\begin{array}{r}1 \\
2 \\
3 \\
4 \\
5 \\
6 \\
7 \\
8 \\
9 \\
10\end{array}$ & $\begin{array}{l}33 \\
42 \\
28 \\
25 \\
25 \\
23 \\
45 \\
56 \\
24 \\
33\end{array}$ & $\begin{array}{l}\mathbf{M} \\
\mathbf{F} \\
\mathbf{F} \\
\mathbf{F} \\
\mathbf{M} \\
\mathbf{M} \\
\mathbf{M} \\
\mathbf{M} \\
\mathbf{M} \\
\mathbf{M}\end{array}$ & $\begin{array}{r}64 \\
64 \\
32 \\
2 \\
128 \\
32 \\
32 \\
32 \\
64 \\
64\end{array}$ & $\begin{array}{r}1024 \\
256 \\
256 \\
32 \\
1024 \\
128 \\
128 \\
128 \\
256 \\
800\end{array}$ & $\begin{array}{r}5120 \\
5120 \\
>5120 \\
5120 \\
1280 \\
1280 \\
5120 \\
5120 \\
5120 \\
5120\end{array}$ & $\begin{array}{r}2 \\
32 \\
4 \\
2 \\
4 \\
8 \\
8 \\
2 \\
16 \\
1\end{array}$ & $\begin{array}{r}8 \\
128 \\
32 \\
32 \\
64 \\
256 \\
64 \\
16 \\
128 \\
0\end{array}$ & $\begin{array}{r}1280 \\
1280 \\
1280 \\
5120 \\
5120 \\
320 \\
5120 \\
1280 \\
1280 \\
320\end{array}$ & $\begin{array}{r}4 \\
4 \\
4 \\
4 \\
6 \\
8 \\
13 \\
19 \\
45 \\
67\end{array}$ & $\begin{array}{l}1 \\
1 \\
1 \\
1 \\
2 \\
2 \\
2 \\
5 \\
7 \\
1\end{array}$ & $\begin{array}{l}\text { Excellent } \\
\text { Good } \\
\text { Excellent } \\
\text { Poor } \\
\text { Excellent } \\
\text { Good } \\
\text { Good } \\
\text { Excellent } \\
\text { Good } \\
\text { Excellent }\end{array}$ \\
\hline
\end{tabular}


Therapeutic effect of oral doxycycline on syphilis

Table 6 Laboratory data for a 33-year-old male patient with late latent syphilis who had had alopecia due to a previous infection

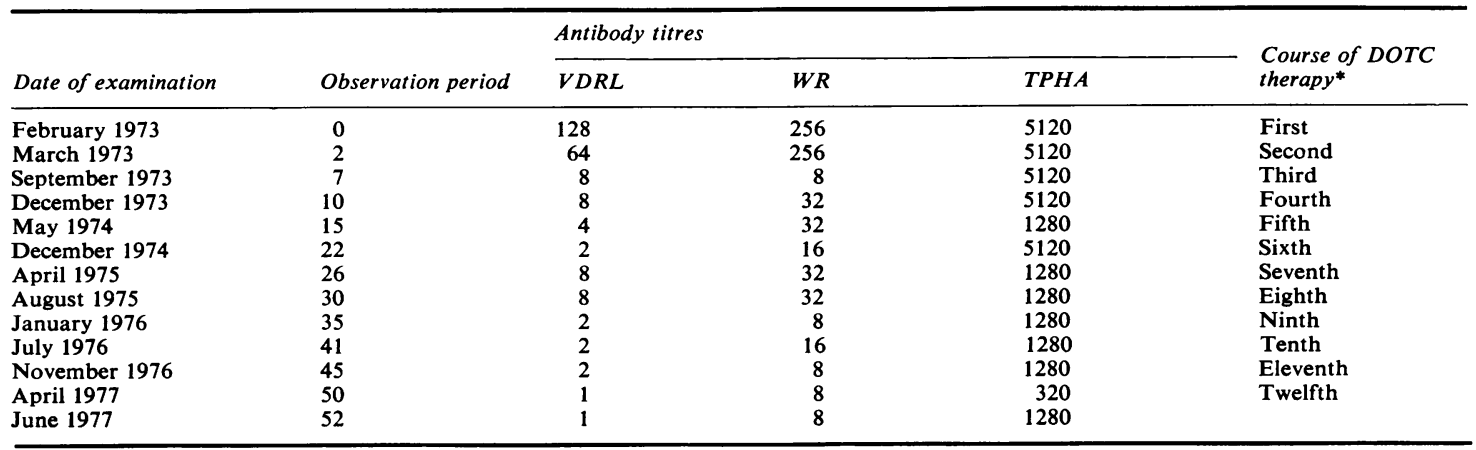

*Each course consisted of $200 \mathrm{mg}$ doses daily for 28 days

Table 7 Laboratory data for 16 patients with late syphilis

\begin{tabular}{|c|c|c|c|c|c|c|c|c|c|c|c|}
\hline \multirow[b]{3}{*}{ Case no.* } & \multirow[b]{3}{*}{ Age (yrs) } & \multirow[b]{3}{*}{ Sex } & \multicolumn{6}{|c|}{ Antibody titres } & \multirow{3}{*}{$\begin{array}{l}\text { Observation } \\
\text { period }\end{array}$} & \multirow{3}{*}{$\begin{array}{l}\text { No. of } \\
\text { courses of } \\
\text { DOTC } \\
\text { therapy }\end{array}$} & \multirow[b]{3}{*}{ Response } \\
\hline & & & \multicolumn{3}{|c|}{ Before treatment } & \multicolumn{3}{|c|}{ After treatment } & & & \\
\hline & & & $V D R L$ & $W R$ & $T P H A$ & $V D R L$ & $W R$ & $T P H A$ & & & \\
\hline (1) & 37 & F & 1 & 0 & 80 & 0 & 0 & 80 & 4 & 1 & Excellent \\
\hline (2) & 65 & $\mathbf{M}$ & 4 & 16 & 1280 & 2 & 8 & 1280 & 4 & 1 & Good \\
\hline (3) & 55 & $\mathbf{M}$ & 2 & 4 & 320 & 2 & 32 & 320 & 13 & 3 & Poor \\
\hline 4 & 63 & $\mathbf{M}$ & 2 & 32 & 1280 & 2 & 8 & 1280 & 15 & 3 & Good \\
\hline $\begin{array}{l}4 \\
5\end{array}$ & 33 & $\mathrm{~F}$ & 1 & 16 & 320 & 1 & 4 & 320 & 16 & 4 & Good \\
\hline 6 & 29 & $\mathbf{M}$ & 4 & 8 & 320 & 2 & 4 & 320 & 16 & 4 & Good \\
\hline 7 & 52 & $\mathbf{M}$ & 1 & 8 & 320 & 2 & 8 & 320 & 16 & 2 & Poor \\
\hline 8 & 55 & $\mathbf{M}$ & 2 & 8 & 320 & 1 & 0 & 80 & 23 & 4 & Excellent \\
\hline 9 & 38 & $\mathbf{M}$ & 16 & 160 & 320 & 4 & 8 & 320 & 26 & 7 & Excellent \\
\hline (10) & 65 & $\mathrm{~F}$ & 128 & 1024 & 5120 & 64 & 512 & 5120 & 26 & 7 & Good \\
\hline (11) & 52 & $\mathbf{M}$ & 32 & 256 & 5120 & 32 & 128 & 5120 & 26 & 4 & Poor \\
\hline (12) & 45 & $\mathbf{F}$ & 8 & 16 & 320 & 4 & 16 & 5120 & 40 & 7 & Poor \\
\hline 13 & 51 & $\mathbf{F}$ & 8 & 32 & 320 & 2 & 8 & 1280 & 48 & 10 & Excellent \\
\hline 16 & 31 & $\mathbf{M}$ & 8 & 32 & 1280 & 2 & 16 & 5120 & 58 & 12 & Good \\
\hline
\end{tabular}

*Case nos. in parenthesis indicate those having had previous treatment

Table 8 Laboratory data for a 23-year-old female patient with adult congenital syphilis

\begin{tabular}{|c|c|c|c|c|c|}
\hline \multirow[b]{2}{*}{ Date } & \multirow[b]{2}{*}{ Observation period } & \multicolumn{3}{|c|}{ Antibody titres } & \multirow{2}{*}{$\begin{array}{l}\text { Course of DOTC } \\
\text { therapy }\end{array}$} \\
\hline & & $V D R L$ & $W R$ & TPHA & \\
\hline February 1970 & 0 & 16 & 128 & 81920 & First \\
\hline November 1970 & 9 & 32 & 128 & 20480 & Third \\
\hline May 1971 & 15 & 8 & 128 & 5120 & Fourth \\
\hline November 1971 & 21 & 16 & 32 & 5120 & Fifth \\
\hline May 1972 & 27 & 8 & 64 & 5120 & Sixth \\
\hline October 1972 & 32 & 16 & 64 & 5120 & Seventh \\
\hline March 1973 & 37 & 16 & 128 & 5120 & Eighth \\
\hline July 1973 & 41 & 8 & 32 & 5120 & Ninth \\
\hline February 1974 & 48 & 8 & 32 & 5120 & Eleventh \\
\hline November 1974 & 57 & 16 & 64 & 5120 & Thirteenth \\
\hline March 1975 & 61 & 8 & 64 & 5120 & Fourteenth \\
\hline November 1975 & 69 & 8 & 32 & 5120 & Sixteenth \\
\hline March 1976 & 73 & 8 & 64 & 5120 & Seventeenth \\
\hline November 1976 & 81 & 8 & 32 & 5120 & Nineteenth \\
\hline March 1977 & 85 & 8 & 64 & 5120 & Twentieth \\
\hline July 1977 & 89 & 8 & 128 & 5120 & Twenty-first \\
\hline September 1977 & 91 & 4 & 16 & 5120 & - \\
\hline November 1977 & 93 & 4 & 32 & 5120 & - \\
\hline
\end{tabular}


Table 9 Laboratory data for 20 patients with adult congenital syphilis

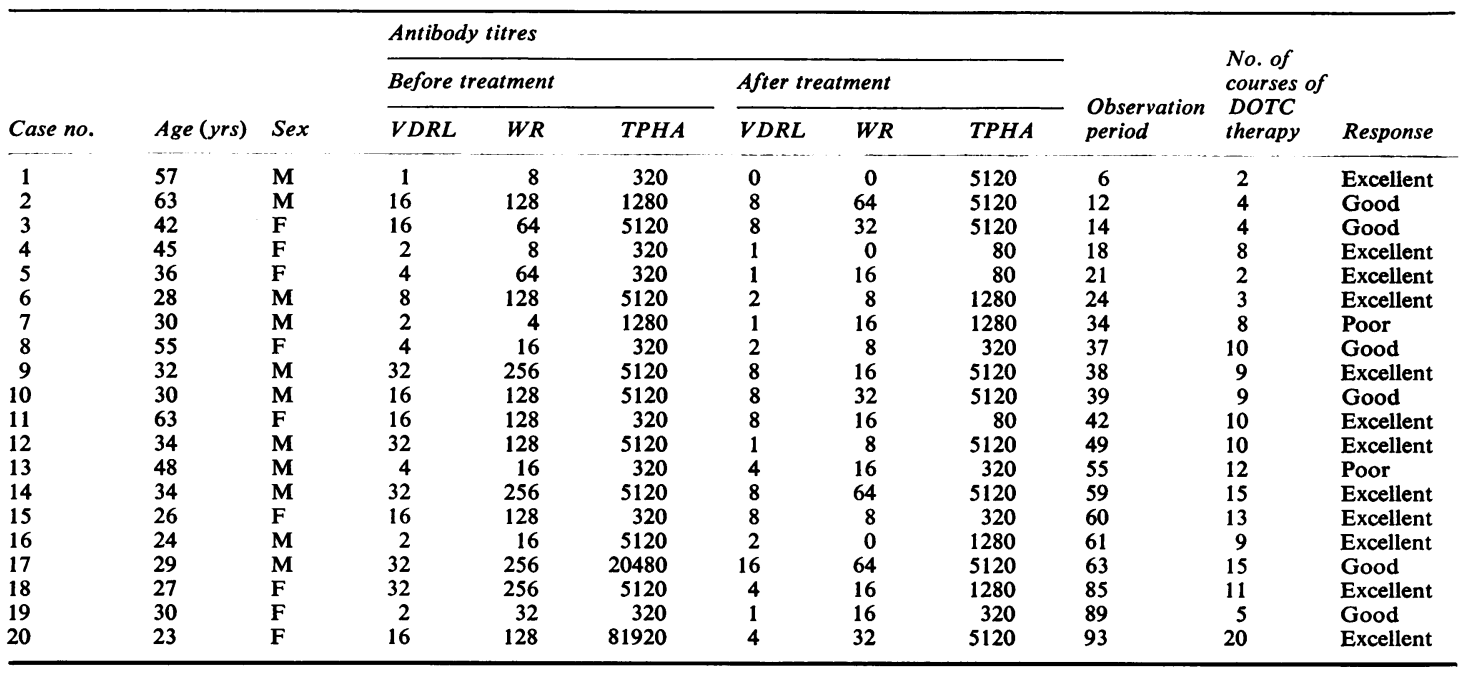

SGOT and SGPT levels remained within normal range during the entire period of observation in each case. Herxheimer's phenomenon was not observed even in those patients with primary and secondary syphilis.

\section{Discussion and conclusion}

Oral penicillins, cephalexins, macrolides, and tetracyclines are effective in the treatment of syphilis. Oral administration of these antibiotics is inconvenient since they should be taken every six hours to maintain an effective blood concentration. Unless the regimen is strictly followed, satisfactory results will not be obtained even with the most potent drugs. Oral antibiotics characterised by long-lasting effective blood concentrations are required for the treatment of syphilis where effective blood concentrations should be maintained without interruption over prolonged periods of time.

DOTC was found to satisfy these criteria for the treatment of syphilis. Two daily doses were sufficient to maintain effective blood concentrations, and such a regimen was convenient for patients. Few side effects developed because daily doses were low. Generally, patients followed the regimen precisely, and changes in antibody titres due to the therapy could be serially observed.

Alexander and Schoch (1966), Steppert (1968), and Wodniansky et al. (1969) have reported their short-term observations of patients after treatment with DOTC, and they all noticed excellent results. I have also treated a patient with primary syphilis using DOTC $100 \mathrm{mg}$ daily for 14 consecutive days with excellent results. Tsutogawa et al. (1971), Minami et al. (1972) and Maruta and Shirouzu (1973) reported good results using the same dose of DOTC for patients with syphilis.

The overall effective rates in this study were $100 \%$ for patients with primary syphilis, $90 \%$ for those with early syphilis, $68 \cdot 7 \%$ for those with late syphilis ( $90 \%$ for those without previous treatment), and $90 \%$ for those with adult congenital syphilis (Table 10).

Table 10 Summary of the effects of oral doxycycline treatment for syphilis

\begin{tabular}{|c|c|c|c|c|c|c|c|}
\hline \multirow[b]{3}{*}{ Stage of syphilis } & \multicolumn{6}{|c|}{ Response and number of patients treated } & \multirow{3}{*}{ Total no. of cases } \\
\hline & \multicolumn{2}{|c|}{ Excellent } & \multicolumn{2}{|c|}{ Good } & \multicolumn{2}{|c|}{ Poor } & \\
\hline & No. & $\%$ & No. & $\%$ & No. & $\%$ & \\
\hline $\begin{array}{l}\text { Primary } \\
\text { Early } \\
\text { Late } \\
\text { Adult congenital }\end{array}$ & $\begin{array}{r}5 \\
5 \\
6 \\
12\end{array}$ & $\begin{array}{r}100 \cdot 0 \\
50 \cdot 0 \\
37 \cdot 5 \\
60 \cdot 0\end{array}$ & $\begin{array}{l}0 \\
4 \\
6 \\
6\end{array}$ & $\begin{array}{l}0 \\
40 \cdot 0 \\
37 \cdot 5 \\
30 \cdot 0\end{array}$ & $\begin{array}{l}0 \\
1 \\
4 \\
2\end{array}$ & $\begin{array}{l}0 \\
10 \cdot 0 \\
25 \cdot 0 \\
10 \cdot 0\end{array}$ & $\begin{array}{r}5 \\
10 \\
16 \\
20\end{array}$ \\
\hline
\end{tabular}


Onoda et al. (1977) treated 61 cases of syphilis with amoxycillin for two years in a previous clinical trial. This oral treatment was effective in $100 \%$ of cases of primary and early syphilis, in $66.7 \%$ of cases of late syphilis, and in $60 \%$ of cases of adult congenital syphilis.

Treatment with both amoxycillin and DOTC proved effective in $100 \%$ of cases of primary syphilis. For early syphilis, the effective rate with DOTC therapy was lower than that with amoxycillin therapy, although the difference did not seem to be significant. Also, there was no significant difference between the therapeutic effect of amoxycillin and DOTC on late syphilis. Treatment with DOTC was more effective than with amoxycillin for adult congenital syphilis, probably because of the longer observation periods used for the former therapy than for the latter.

The antisyphilitic effect of oral DOTC was proved to be comparable or somewhat superior to that of oral penicillins, probably because less frequent doses were required with DOTC than with penicillins. The more frequent the daily doses the more easily patients would forget to take the drug. In addition, few side effects were caused by DOTC treatment. Thus, oral DOTC therapy is suitable for the treatment of late syphilis and congenital syphilis in adults, which require treatment over long periods of time.

As a result of the introduction of penicillins the number of patients with syphilis has been notably reduced. The disease has by no means been eradicated, however, but its incidence has tended to increase in recent years. Injections of penicillins may be contraindicated in occasional cases and, generally, patients prefer oral administration to injection. The development of satisfactory oral antibiotic treatment regimens for syphilis, such as discussed in this paper, are needed.

\section{References}

Alexander, L. J., and Schoch, A. G. (1966). Doxycycline-HCl in syphilis and gonorrhea. Proceedings of Interscience Conference of Antimicrobial agents and Chemotherapy, 6, 26-28.

Maruta, H., and Shirouzu, G. (1973). Efficacy of vibramycin against syphilis. Journal of New Remedies and Clinics, 22, 147-149.

Minami, K., Tashiro, M., Kuwabara, T. and Fukuzaki, M. (1972). Clinical experience with vibramycin in the treatment of the syphilis and soft chancre. Japanese Journal of Clinical Experience and Medicine, 49, 200-205.

Onoda, Y. (1970). Changes in titres of the serological tests for syphilis due to treatment. Venereal Disease, 51, 32-38.

Onoda, Y., Miki, Y., Minami, K., Nakamura, J., Okamoto, S., Sasai, Y., Maruta, H., Inoue, K., Shiratori, A., Tsugami, H., Zenyoji, H., Okubo, N., Fukai, K. (1977). Clinical evaluation of amoxicillin treatment in syphilis. XV International Committee of Dermatology, Mexico City, 20 October 1977.

Steppert, A. (1968). Therapy of bacterial skin infection and venereal diseases. Wiener Medizinische Wochenschrift, 25, 599-602.

Tsutogawa, Y., Kikuchi, T. and Nishio, T. (1971). The effect of vibramycin in the treatment of syphilis. West Japan Dermatology, $33,46-48$.

Wodniansky, P., Holubar, K. and Philippu, G. (1969). Treatment of early syphilis with vibramycin. Preliminary information. Report from the First University Dermatologic Clinic of Vienna, November 1969. 